\title{
Inhibitory Efficacy of Smilax china L. on Pro-collagen Type-1 Activity and MMP-1 Gene Expression in Fibroblasts (CCD-986sk)
}

\author{
Soo-Yeon Lee and Jin-Young Lee*
}

Department of Herbal Cosmetic Science, Hoseo University, Asan, Chungnam 336-795, Karea

Received July 8, 2013 /Revised August 28, 2013 /Accepted October 23, 2013

\begin{abstract}
The purpose of this study was to research the biological activity of ethanol extract from Smilax china L. which is a vine shrub belonging to the lily family. For antiwrinkle effects, elastase inhibition effect of ethanol and water extracts from S. china L. showed $41.1 \%$ and $16.3 \%$ at $1,000 \mu \mathrm{g} / \mathrm{ml}$ concentration. The collagenase inhibition effect of ethanol and water extracts from S. china L. showed more than $96.6 \%$ and $60.0 \%$ at $1,000 \mu \mathrm{g} / \mathrm{ml}$ concentration. As a result of having fibroblast measured cell viability on fibroblast cell of ethanol extract from S. china L., it showed $71.7 \%$ with cell viability at $100 \mu \mathrm{g} / \mathrm{ml}$ concentration. At $50 \mu \mathrm{g} / \mathrm{ml}$ concentration, the procollagen biosynthesis effect of ethanol extract from S. china L. was $139.86 \%$. At the same concentration, the matrix metalloprotease (MMP)-1 inhibition effect of the ethanol extract was $74.9 \%$. According to the results of Western blot of ethanol extract from $S$. china L., the expression of the MMP-1 protein was decreased by $35 \%$ at $50 \mu \mathrm{g} / \mathrm{ml}$ concentration. Reverse transcription-polymerase chain reaction (PCR) of ethanol extract from $S$. china L. showed that the expression of MMP-1 mRNA was decreased by $45 \%$ at $50 \mu \mathrm{g} / \mathrm{ml}$ concentration. The findings suggest that $70 \%$ ethanol extract from $S$. china $\mathrm{L}$. (SC) has great potential as a cosmeceutical ingredient with antiwrinkle effects.
\end{abstract}

Key words : Anti-wrinkle, MMP-1, pro-collagen, Smilax china L.

\section{서 론}

세포 외 기질(extracellular matrix)의 주요 구성 성분인 콜 라겐(collagen)은 피부의 섬유아 세포에서 생성되는 주요 기질 단백질이다. 또한 생체 단백질 총 중량의 약 $30 \%$ 를 차지하는 중요한 단백질로서 견고한 3중 나선구조를 가지고 있다. 콜라 겐은 피부, 건(tendon), 뼈 및 치아의 유기 물질의 대부분을 형성하는데, 특히 뼈와 피부의 진피에 그 함유량이 많다. 콜라 겐의 주된 기능으로는 피부의 기계적 견고성, 결합조직의 저 항력과 조직의 결합력, 세포 접착의 지탱, 세포 분할과 분화의 유도 등이 알려져 있다[6]. 이러한 콜라겐은 연령 및 자외선 조사에 의한 광노화에 의해 감소하며, 이는 피부의 주름 형성 과 밀접한 연관이 있다고 알려져 있다[3, 4, 17]. 콜라겐은 대부 분 피부의 진피층에 존재하며, 피부 전체 건조 중량의 약 70 90\%를 차지하고 있어, 세포 외 기질의 대부분을 차지하면 서 피부를 지지하는 역할을 한다. 보통 피부에서 I 형 콜라겐 의 합성과 그 분해효소인 matrixmetalloprotease (MMP)- 1 의 활성이 균형을 이루고 있지만, 내외적인 원인으로 인해 I 형

\section{*Corresponding author}

Tel : +82-41-540-9552, Fax : +82-41-540-9538

E-mail : jylee@hoseo.edu

This is an Open-Access article distributed under the terms of the Creative Commons Attribution Non-Commercial License (http://creativecommons.org/licenses/by-nc/3.0) which permits unrestricted non-commercial use, distribution, and reproduction in any medium, provided the original work is properly cited.
과 III형 콜라겐의 합성이 저하되고, $\mathrm{MMP}-1$ 의 활성이 증가되 는 것으로 알려져 있다[7, 9, 15]. 따라서 콜라겐 분해는 결합조 직의 탄력저하와 주름생성 등에 직접적인 영향을 미친다. 체 내에서 생성되는 수십 종의 MMPs 가운데 MMP- 1 은 콜라겐 에 특이적으로 작용하는 단백질분해효소(proteinase)로서 MMP-1의 활성을 억제하여 콜라겐의 분해를 감소시키며 피부 조직의 탄력을 유지하고, 주름 생성을 예방할 수 있다[11].

청미래덩굴(Smilax china L.)은 한국, 일본, 중국, 필리핀 및 인도차이나 등의 지역에 분포하며, 우리나라 대부분의 산야에 서 서식하는 백합과(Lilaceae)에 속하는 덩굴성 관목으로 지역 에 따라 청미래덩굴, 명감나무, 매발톱가시, 참열매덩굴, 종가 시덩굴 등 다양하게 불리고 있으며, 원예 분야에서는 멍개나 무 또는 망개나무로 잘 알려져 있다. 잎은 넓은 타원형으로 광택이 있으며 두껍고, 5월에 황록색의 꽃이 피며, 9-10월에 둥근 열매가 빨갛게 익는다. 어린순과 열매는 식용을 하고, 뿌리와 나무는 해열, 해독, 이뇨 등의 증상 완화, 체력증강 및 피부염, 신장염, 방광염, 항균작용, 관절염, 유방암 등에 효과 가 있다고 알려져 있다[13,14,18]. 청미래덩굴의 함유 성분으 로는 pseudoprotodioscin, dioscin, protodioscin, sieboldogenin, glycoside 등이 있다. 또한 청미래덩굴(Smilax china L.)의 근경을 지칭하는 토복령의 성분에 관한 연구는 아직 많지는 않지만 saponin, tannin 등이 주성분이라고 알려져 있으며, 뿌 리에서 분리된 배당체 ophiopogonin과 점액성 물질이 많이 포함되어 인체의 면역 증진과 각종 세균의 감염으로부터 장기 를 보호하는데 중요한 역할을 한다고 알려져 있으며 또한 중 
금속 중독에 대한 해독 작용에 효과적이라고 알려져 있다[20]. 청미래덩굴에 관한 연구는 청미래덩굴 추출물의 항산화, 항균 에 관한 연구는 보고되어있으나 청미래덩굴의 항노화에 관한 내용은 보고되지 않은 상태이다.

따라서 본 연구에서는 청미래덩굴 추출물을 이용하여 elastase, collagenase 저해활성과 섬유아세포에서의 pro-collagen 생합성량, MMP-1 저해활성, MMP- 1 의 단백질 발현 및 $\mathrm{mRNA}$ 발현억제 효과를 확인하여 주름개선용 화장품 소재로 서의 가능성을 살펴보고자 한다.

\section{재료 및 방법}

\section{재료}

본 실험에 사용된 청미래덩굴은 충북 괴산에서 2012년 봄에 생산 된 건채를 구입하여 추출시료로 사용하였다. 시료의 에 탄올 추출물은 $70 \%$ 에탄올 10 배의 양을 가하여 실온에서 24 시 간 침지하여 상등액과 침전물을 분리하여 동일한 방법으로 3 회 반복 추출하였고, 열수 추출물은 증류수 10 배의 양을 가하 여 $80^{\circ} \mathrm{C}$ 에서 3 시간 가량 환류냉각 추출해 실온에서 24 시간 침지하여 상등액과 침전물을 분리하여 동일한 방법으로 3 회 반복 추출하였다. 각 시료 추출물은 여과지(Whatman No.2)를 이용하여 여과한 후 EYELA evaporator로 감압 농축하여 용매 를 완전히 제거한 후 동결 건조하여 $-20^{\circ} \mathrm{C}$ 에 보관하면서 본 실험의 시료로 사용하였으며, 효소 실험 후 활성이 우수한 에 탄올 추출물을 이용하여 세포실험을 실시하였다.

\section{Elastase 저해활성 측정}

Elastase 저해활성 측정은 Cannell 등의 방법[1]에 따라 측 정하였다. 기질로서 N-succinyl-(L-Ala) 3 -p-nitroanilide (Sigma, U.S.A)를 사용하여 $37^{\circ} \mathrm{C}$ 에서 30 분간 기질로부터 생성되는 p-nitroanilide의 생성량을 $445 \mathrm{~nm}$ 에서 측정하였다. 즉, 각 시 험용액을 일정 농도가 되도록 조제하여 $40 \mu \mathrm{l}$ 씩 96-well plate 에 취하고, $50 \mathrm{mM}$ Tris- $\mathrm{HCl}$ buffer ( $\mathrm{pH}$ 8.6)에 녹인 $2.5 \mathrm{U} / \mathrm{ml}$ porcine pancreas elastase (Sigma, U.S.A) 용액 $40 \mu 1$ 을 가한 후 기질로 $50 \mathrm{mM}$ Tris- $\mathrm{HCl}$ buffer ( $\mathrm{pH}$ 8.6)에 녹인 N-succinyl-(L-Ala) $)_{3}$-p-nitroanilide $(0.5 \mathrm{mg} / \mathrm{ml})$ 을 $80 \mu \mathrm{l}$ 첨가하여 30 분 간 반응시켜 기질로부터 생성되는 p-nitroanilide의 생성량을 $445 \mathrm{~nm}$ 에서 측정하였다. Elastase 저해활성은 시료용액의 첨 가군과 무첨가군의 흡광도 감소율로 나타내었다.

$$
\text { 저해율 }(\%)=\left(1-\frac{\text { 시료첨가군의 흡광도 }}{\text { 무첨가군의 흡광도 }}\right) \times 100
$$

\section{Collagenase 저해활성 측정}

Collagenase 저해활성 측정은 Wûnsch E와 Heindrich HG 의 방법[19]에 따라 측정하였다. 즉 반응군은 $0.1 \mathrm{M} \mathrm{Tris}-\mathrm{HCl}$ buffer ( $\mathrm{pH}$ 7.5)에 $4 \mathrm{mM} \mathrm{CaCl}$ 를 첨가하여, $0.3 \mathrm{mg} / \mathrm{ml}$ 의 4-phenyl azobenzyloxycarbonyl-Pro-Leu-Gly-Pro-D-Arg (Sigma, U.S.A)를 녹인 기질액 $125 \mu \mathrm{l}$ 및 시료용액 $50 \mu \mathrm{l}$ 의 혼합액에 $0.2 \mathrm{mg} / \mathrm{ml}$ 의 collagenase (Sigma, U.S.A) $75 \mu \mathrm{l}$ 를 첨가하여 실온에서 20 분간 방치한 후 $6 \%$ citric acid $250 \mu$ 을 넣어 반응 을 정지 시킨 후, ethyl acetate $1.5 \mathrm{ml}$ 을 첨가하여 $320 \mathrm{~nm}$ 에서 흡광도를 측정하였다. Collagenase 저해활성은 시료용액의 첨 가군과 무첨가군의 흡광도 감소율로 나타내었다.

$$
\text { 저해율 }(\%)=\left(1-\frac{\text { 시료첨가군의 흡광도 }}{\text { 무첨가군의 흡광도 }}\right) \times 100
$$

\section{Pro-collagen type-1 생합성 kit 측정}

세포를 $1 \times 10^{4}$ cells/well 농도로 96 well plate에 접종한 후, 각 well에 시료를 첨가하여 $\mathrm{CO}_{2}$ 배양기에서 24시간 배양하였 다. 이렇게 실험한 세포의 배양액을 모아 실험에 사용하였다. 세포 배양액 내 콜라겐 생합성 정도는 procollagen type- I C peptide (PIP) EIA kit (Takara Bio, Japan)을 사용하여 propeptide의 양을 측정하였다.

\section{Matrix metalloproteinase (MMP)-1 저해활성 kit 측정}

세포를 $1 \times 10^{4}$ cells/well 농도로 96 well plate에 접종한 후, 각 well에 시료를 첨가하여 $\mathrm{CO}_{2}$ 배양기에서 24시간 배양하였 다. 이때 MMP-1의 활성을 높이기 위하여 TNF- $a$ 를 $10 \mathrm{ng} / \mathrm{ml}$ 의 농도로 첨가하였다. 세포의 배양액을 수거하여 실험에 사 용하였으며 Gross B.E 등의 방법[5]에 따라 MMP-1 biotrack activity assay kit (Amersham Bioscience, NJ, USA)을 이용하 여 측정하였다.

\section{세포 배양}

본 실험에 이용한 각 세포의 배양은 $10 \% \mathrm{FBS}$ 와 $1 \%$ penicillin/streptomycin $(100 \mathrm{U} / \mathrm{ml})$ 을 첨가한 DMEM 배지를 사 용하였으며, $37^{\circ} \mathrm{C}, 5 \% \mathrm{CO}_{2}$ 세포배양기에 적응시켜 계대 배양 하였다.

\section{3-(4,5-dimethylthiazol-2-y)-2,5-diphenyl}

tetrazolium bromide (MTT) assay에 의한 세포 생존율 측정

세포 생존율 측정은 Carmichael의 방법[2]에 따라 측정하였 다. 섬유아세포(CCD-986sk)을 96 well plate에 $5 \times 10^{4}$ cells/ well이 되게 $0.18 \mathrm{ml}$ 분주하고, 시료를 농도 별로 조제하여 $0.02 \mathrm{ml}$ 첨가한 후 $37^{\circ} \mathrm{C}, 5 \% \mathrm{CO}_{2}$ incubator에서 24 시간 배양하 였다. 대조군은 시료와 동량의 증류수를 첨가하여 동일한 조 건으로 배양하였다. 여기에 $5 \mathrm{mg} / \mathrm{ml}$ 농도로 제조한 MTT 용 액 $0.02 \mathrm{ml}$ 를 첨가하여 4 시간 배양한 후 배양액을 제거하고 각 well당 DMSO $0.15 \mathrm{ml}$ 를 가하여 실온에서 30 분간 반응시킨 뒤 ELISA reader로 $540 \mathrm{~nm}$ 에서 흡광도를 측정하였다. 세포 독성 측정은 시표용액의 첨가군과 무첨가군의 흡광도 감소율 로 나타내었다. 
세포 생존율 $(\%)=\left(1-\frac{\text { 시료첨가군의 흡광도 }}{\text { 무첨가군의 흡광도 }}\right) \times 100$

\section{Western blot을 통한 단백질의 발현 측정}

MMP-1의 활성을 보기 위하여 CCD-986sk 세포주를 100 $\mathrm{mm}$ tissue culture dish에 분주하고 24시간 동안 배양하여 세 포를 안정화 시켰다. 배지를 제거한 후 추출물을 농도별로 처 리한 배지로 24 48시간 배양한 후 다시 배지를 제거하고 phosphate buffered saline (PBS)로 2번 세척해주었다. Radioimmunoprecipitation assay (RIPA) buffer $10 \mathrm{ml}$ 에 complete $\operatorname{mini} 1 \mathrm{tab}$ 를 가한 $100 \mu$ l로 용해해서 $4^{\circ} \mathrm{C} 13,200 \mathrm{rpm}$ 에서 20분 간 원심 분리하였다. 원심 분리하여 얻은 상층액은 BCA protein assay kit (Thermo scienctific, USA)를 사용하여 정량하여 $20 \mu \mathrm{l}$ 의 단백질을 $10 \%$ SDS-PAGE 상에서 전기영동하여 분리 하였다. 분리된 단백질은 semi dry transfer cell 기기(Hofer, USA)를 이용하여 polyvinylidene fluoride (PVDF) membrane 에 옮긴 다음 실온에서 1시간 blocking buffer (5\% skim milk in TBST)에서 배양시켰다. 1 차 항체를 희석하여 $4^{\circ} \mathrm{C}$ 에서 하루 동안 반응시키고 다시 10분 간격으로 Tris-buffered saline and tween 20 (TBST)로 3회 세척하고 2차 항체를 1:1,000으로 희석 하여 실온에서 2 시간 배양하였다. 3 희 세척한 후 LAS 4,000 기기를 이용하여 밴드 확인 및 정량하였다.

\section{Total RNA 분리 및 CDNA 합성}

세포를 $100 \mathrm{~mm}$ culture dish에 세포를 분주한 뒤 24시간 동안 배양한 후 sample을 농도별로 처리하여 24시간 동안 배 양하였다. 배지 상등액을 제거한 후 trizol lysis buffer를 각 well에 $1 \mathrm{ml}$ 씩 분주하여 세포를 lysis 한 후 chloroform 200 $\mu 1$ 를 분주하여 20 초간 위아래로 흔들어주었다. 그 후 13,200 $\mathrm{rpm}$ 에서 20 분간 원심 분리하여 상층액을 isopropanol $500 \mu \mathrm{l}$ 이 들어있는 튜브에 옮겨 섞었다. 다시 $13,200 \mathrm{rpm}$ 에서 20 분간 원심분리 하였고, 그 상층액을 제거 한 후 $75 \% \mathrm{EtOH}-$ diethylpyrocarbonate water를 각 튜브에 $1 \mathrm{ml}$ 씩 분주하여 13,200 $\mathrm{rpm}$ 에서 5 분간 원심분리 한 뒤 상층액을 제거한 뒤 실온에서 건조시켰다. $\mathrm{DEPC}$ 를 $50 \mu \mathrm{l}$ 씩 분주하여 녹인 후 96 well plate 에 RNA 5 ul와 멸균수 $195 \mu$ 를 첨가하여 $260 \mathrm{~nm}, 280 \mathrm{~nm}$ 에서 각각 흡광도를 측정하여 total RNA양을 측정하였다. Oligo (dT) 15 primer $(500 \mu \mathrm{g} / \mathrm{ml}) 1 \mu \mathrm{l}$, 추출한 RNA (2 $\mu \mathrm{g})$ 와 nuclease free water로 $10 \mu 1$ 를 맞추고 $75^{\circ} \mathrm{C}$ 에서 5 분간 반응시킨 후
5X reaction buffer, $\mathrm{MgCl}_{2}$, PCR necleotide mix, ribonuclease inhibitor, reverse transcriptase, ruclease free water (Promega Corporation, USA)를 첨가하여 $25^{\circ} \mathrm{C}$ 에서 5 분, $42^{\circ} \mathrm{C}$ 에서 60 분, $70^{\circ} \mathrm{C}$ 에서 15 분간 반응시켜 $\mathrm{cDNA}$ 를 합성시켰다.

\section{Reverse transcription-polymerase chain reaction}

Matrix metalloproteinase-1 (MMP-1)의 mRNA 발현을 알 아보기 위하여 polymerase chain reaction (PCR)을 실시하였 다. 실험에 사용한 primer sequences는 Table 1과 같다. PCR tube에 Taq DNA polymerase (Promega Corporation, USA), primer, 합성한 $\mathrm{cDNA}$ 를 첨가하여 잘 섞은 후 $\mathrm{PCR}$ 을 실행하 였다. MMP- 1 은 $94^{\circ} \mathrm{C}$ 에서 30 초, $56^{\circ} \mathrm{C}$ 에서 60 초, $72^{\circ} \mathrm{C}$ 에서 1 분 (35 cycles)를 하였다. PCR로 합성 시킨 후 $0.002 \%$ ethidium bromide를 첨가한 $1.5 \%$ agarose gel에 $100 \mathrm{~V}$ 에서 40 분간 전기 영동 후 LAS 4,000 을 이용하여 밴드를 확인하여 분석 정량하 였다.

\section{통계처리}

모든 실험은 3회 반복으로 행하여 평균치와 표준편차로 나 타내었고, 결과 통계처리는 SPSS10.0 (Evanston, IL, USA) software를 사용하였으며, 유의차 검증은 분산분석 (analysis of variance ANOVA)을 한 후 $\mathrm{a}=0.05$ 수준에서 Turkey's HSD test에 의해 유의성을 분석하였다.

\section{결과 및 고찰}

\section{Elastase 저해활성 측정 결과}

청미래덩굴 에탄올 및 열수 추출물의 elastase 저해효과를 측정한 결과 Fig. 1 과 같이 $1,000 \mu \mathrm{g} / \mathrm{ml}$ 에서 각각 $41.1 \%, 16.3 \%$ 로 청미래덩굴 에탄올 추출물의 활성이 우수하였다. 이는 $\mathrm{Lim}$ 등[10]의 포공영 에탄올 추출물과 열수 추출물 $1,000 \mu \mathrm{g} / \mathrm{ml}$ 에 서 각각 $21.6 \%, 12.2 \%$ 의 활성을 나타내었다는 연구 결과와 비 교하였을 때 청미래덩굴 에탄올 추출물의 활성이 우수함을 확인할 수 있었다.

\section{Collagenase 저해활성 측정 결과}

청미래덩굴 에탄올 및 열수 추출물의 collagenase 저해효과 를 측정한 결과 Fig. 2 와 같이 $1,000 \mu \mathrm{g} / \mathrm{ml}$ 에서 각각 $96.6 \%$, $60.0 \%$ 로 청미래덩굴 에탄올 추출물이 더 높은 활성을 나타내

Table 1. Sequence of the primers used for PCR

\begin{tabular}{lll}
\hline Gene & Primer & Sequence $\left(5^{\prime} \rightarrow 3^{\prime}\right)$ \\
\hline \multirow{2}{*}{ MMP-1 } & Forward & AGC GTG TGA CAG TAA GCT AA \\
& Reverse & GTT TTC CTC AGA AAG AGC AGC AT \\
\multirow{2}{*}{$\beta$-actin } & Forward & ATT GTT GCC ATC AAT GAC CC \\
& Reverse & AGT AGA GGC AGG GAT GAT \\
\hline
\end{tabular}




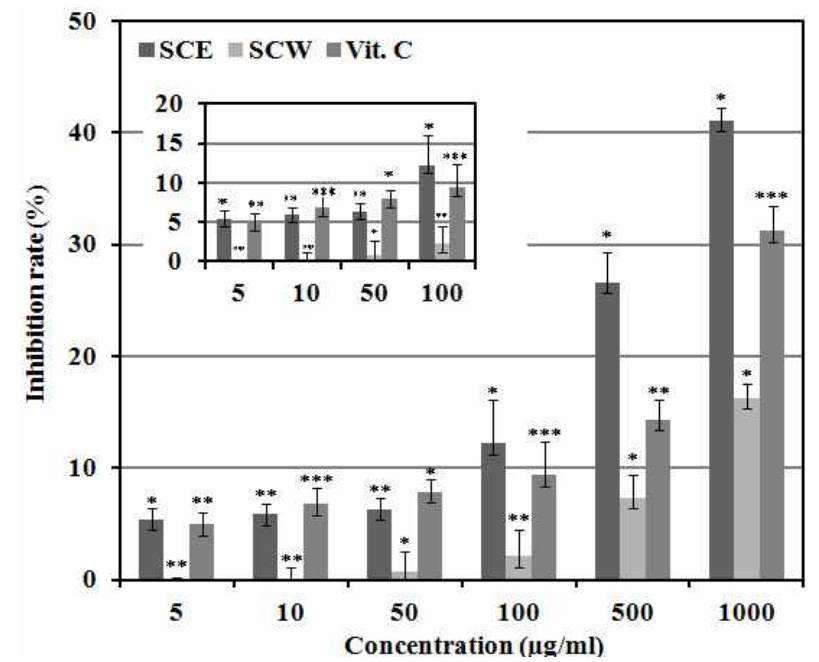

Fig. 1. Inhibition rate activity of Smilax china L. extracts on elastase. $\square$ SCE : Smilax china L. extracted with ethanol, $\square$ SCW : Smilax china L. extracted with water, $\square$ Vit. C: ascorbic acid. Results are means \pm S.D. of triplicate data. (Significant as compared to control. ${ }^{*} p<0.05,{ }^{* *} p<$ $0.01,{ }^{* * *} p<0.001$ )

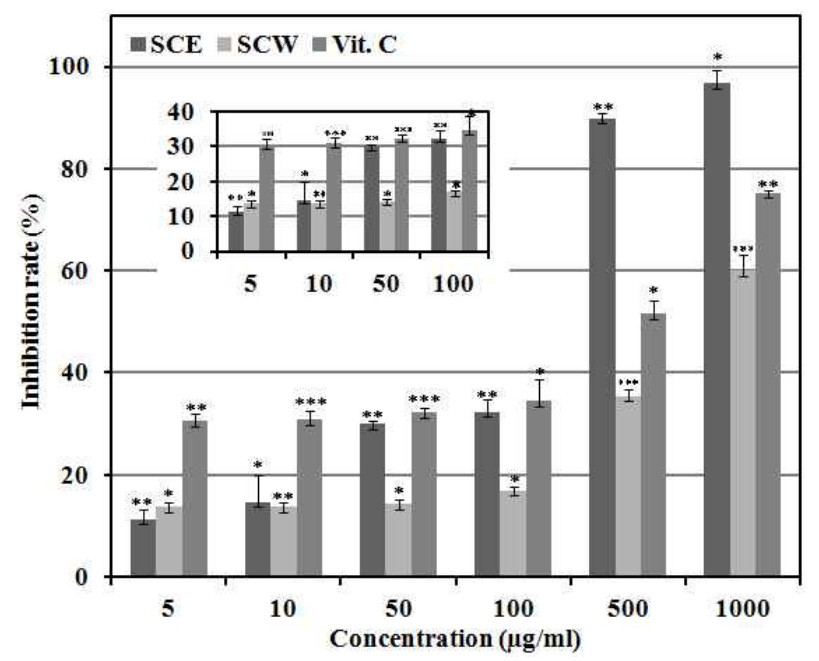

Fig. 2. Inhibition rate activity of Smilax china L. extract on collagenase. $\square$ SCE : Smilax china L. extracted with ethanol, $\square$ SCW : Smilax china L. extracted with water, $\square$ Vit. C: ascorbic acid. Results are means \pm S.D. of triplicate data. (Significant as compared to control. ${ }^{*} p<0.05$, $\left.{ }^{* *} p<0.01,{ }^{* * *} p<0.001\right)$

었다. 이는 Seo [12]의 연구에서 녹두의 열수 추출물은 활성을 나타내지 않았고, 에탄올 추출물은 $1,000 \mu \mathrm{g} / \mathrm{ml}$ 에서 $55.5 \%$ 의 저해능을 나타내었다는 결과와 비교하여 청미래덩굴 에탄올 추출물의 활성이 아주 우수함을 확인할 수 있었으며, 대조군 인 Vit. C가 같은 농도에서 $75.2 \%$ 의 활성을 나타낸 결과를 볼 때 청미래덩굴 에탄올 추출물의 유의한 결과를 확인할 수 있 었다.

\section{섬유아세포(CCD-986sk)의 생존율 확인}

Yellow tetrazolium salt MTT는 담황색 기질로서 살아있는 세포의 미토콘드리아 내의 reductase에 의해 환원되어 formazan을 생성하는데 죽어있는 세포에서는 형성되지 않고 살 아있는 세포의 수가 많을수록 formazan의 생성도 많아지고 세포의 성장을 측정할 수 있다[5]. 이러한 원리를 바탕으로 청 미래덩굴 에탄올 추출물의 세포 생존율을 확인하기 위한 MTT 검색법은 96 well plate를 사용하여 ELISA reader를 이용하여 측정한 결과 Fig. 3과 같이 $100 \mu \mathrm{g} / \mathrm{ml}$ 농도에서 $70 \%$ 이상의 세포 생존율을 확인할 수 있었다. 이하의 섬유아세포(CCD$986 \mathrm{sk})$ 에서의 주름관련 세포 실험은 생존율이 $100 \%$ 에 가까운 농도인 $5,25,50 \mu \mathrm{g} / \mathrm{ml}$ 의 농도로 확인하였다.

\section{섬유아세포(CCD-986sk)에서의 pro-collagen type- I 생합성량 확인}

콜라겐은 대부분 피부의 진피층에 존재하며, 보통 피부에서 I 형 콜라겐의 합성과 그 분해효소인 MMP-1의 활성이 균형 을 이루고 있지만, 내외인적인 원인으로 인해 I 형과 III형 콜 라겐의 합성이 저하되고, MMP-1의 활성이 증가되는 것으로 알려져 있다 $[7,9,15]$. 따라서 콜라겐의 전구체인 pro-collagen 의 c-말단을 인지하는 항체를 이용하여 콜라겐의 생성량을 측 정하는 방법을 이용하여 청미래덩굴 에탄올 추출물의 procollagen 생합성량을 확인한 결과 Fig. 4 와 같이 $5 \mu \mathrm{g} / \mathrm{ml}$ 의 농도에서 $112 \%$ 이상의 효과를 나타내었고, $50 \mu \mathrm{g} / \mathrm{ml}$ 의 농도 에서는 $139 \%$ 이상의 아주 우수한 효과를 나타내었다.

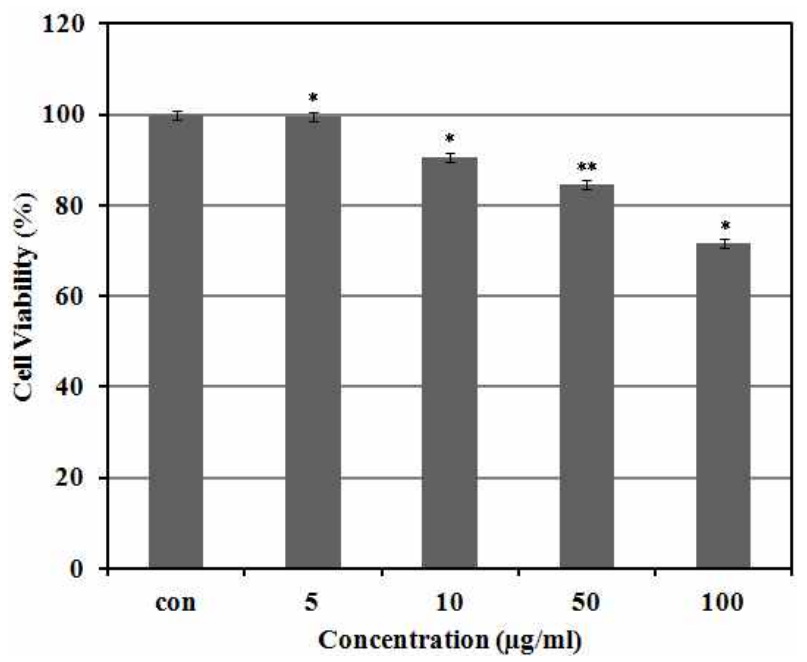

Fig. 3. Cell viability of extract from Smilax china L. on fibroblast cell (CCD-986sk). After CCD-986sk cells $\left(5 \times 10^{4}\right.$ cells) were started in medium for $24 \mathrm{~h}$ the cells were treated with 5, 10, 50 and $100 \mu \mathrm{g} / \mathrm{ml}$ of extracted of Smilax china L. for 24h. Each value represents mean \pm SD of three individual experiments. (Significant as compared to control. ${ }^{*} p<0.05,{ }^{* *} p<0.01,{ }^{* * *} p<0.001$ ) 


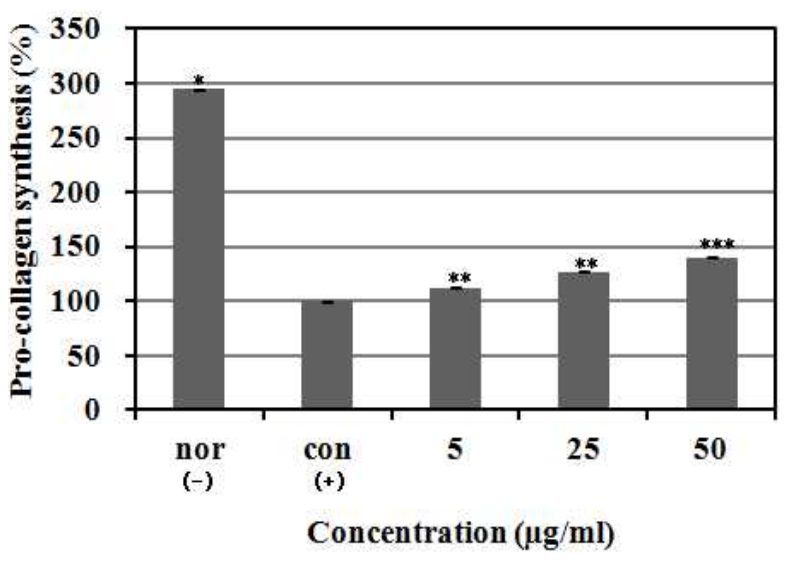

Fig. 4. Pro-collagen synthesis of extract from Smilax china L. on fibroblast cell (CCD-986sk). After CCD-986sk cells $\left(1 \times 10^{4}\right.$ cells) were started in serum free medium for $1 \mathrm{~h}$ the cells were treated with 5,25 and $50 \mu \mathrm{g} / \mathrm{ml}$ of extracted of Smilax china L. for $48 \mathrm{~h}$. Each value represents mean \pm SD of three individual experiments. (Significant as compared to control. ${ }^{*} p<0.05,{ }^{* *} p<0.01,{ }^{* * *} p<0.001$ )

\section{$\mathrm{MMP}-1$ 의 저해활성 측정}

피부 세포의 결합조직을 구성하는 성분 중 콜라겐은 피부 건조 중량의 $70 \sim 90 \%$ 정도를 차지하는 주요 구성 단백질이다. 따라서 콜라겐의 분해는 결합조직의 탄력저하와 주름생성 등 에 직접적인 영향을 미친다. 체내에서 생성되는 수십 종의 $\mathrm{MMPs}$ 가운데 MMP-1은 콜라겐에 특이적으로 작용하는 단백 분해효소로서 MMP-1의 활성을 억제하여 콜라겐의 분해를 감 소시키며 피부조직의 탄력을 유지하고, 주름 생성을 예방할 수 있다[11]. 청미래덩굴 에탄올 추출물을 $5,25,50 \mu \mathrm{g} / \mathrm{ml}$ 의 농도로 첨가하여 MMP-1 저해활성을 측정한 결과 Fig. 5와 같 이 각각의 농도에서 $91.3 \%, 81.9 \%, 74.9 \%$ 의 활성을 나타내어 청미래덩굴 에탄올 추출물의 MMP-1 저해활성이 우수함을 확 인하였고, 이러한 결과 청미래덩굴 에탄올 추출물이 피부 탄 력 및 주름개선 효능에 기여할 것으로 판단된다.

\section{$\mathrm{MMP}-1$ 의 단백질 발현 및 $\mathrm{mRNA}$ 발현억제 효과 확인}

Matrix metalloproteinases (MMPs)는 활성 중심부에 아연 을 갖는 금속 단백질 분해효소로서 현재까지 약 20 여 종 이상 의 종류가 있는 것으로 알려져 있으며, 구조와 기능에 따라 interstitial collagenase, gelatinase, stromelysin, membrane type MMP 등으로 구분하기도 한다[11]. 특히 MMPs는 피부 의 각질형성세포, 섬유아세포를 비롯한 많은 세포들로부터 분 비되어 지지구조체인 세포 외 기질과 기저막을 구성하는 주요 단백질 구성요소들을 가수분해함으로써 피부 탄력을 유지하 는 결합조직을 파괴하여 주름과 탄력 저하 및 피부 처짐의 원인이 되는 것으로 알려져 있다[20]. 따라서 본 연구에서는 MMP family 중 MMP-1의 단백질 발현과 mRNA 발현을 측정 하였다(Fig. 6, 7). 청미래덩굴 에탄올 추출물에서 MMP-1의

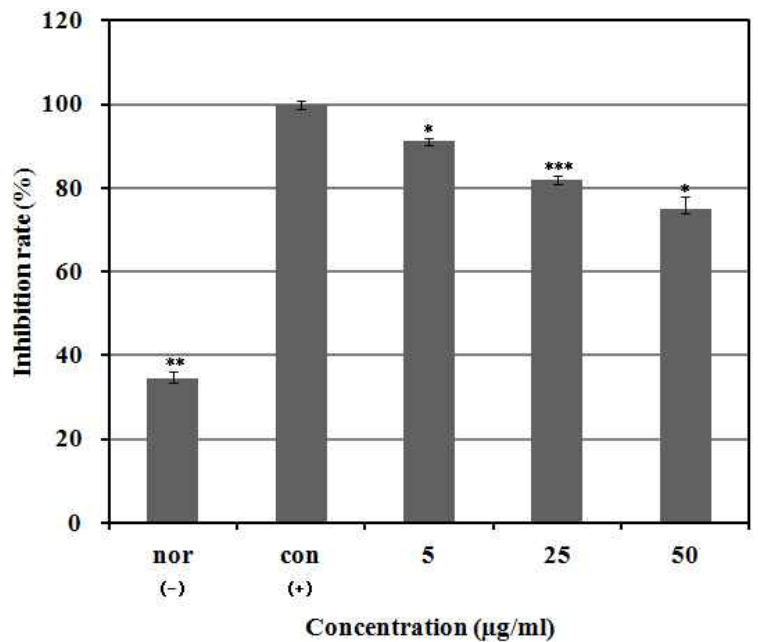

Fig. 5. MMP-1 inhibition rate of extract from Smilax china L. on fibroblast cell (CCD-986sk). After CCD-986sk cells $\left(1 \times 10^{4}\right.$ cells) were started in serum free medium for $1 \mathrm{~h}$ the cells were treated with 5,25 and $50 \mu \mathrm{g} / \mathrm{ml}$ of extracted of Smilax china L. for $48 \mathrm{~h}$. Each value represents mean \pm SD of three individual experiments. (Significant as compared to control. $\left.{ }^{*} p<0.05,{ }^{* *} p<0.01,{ }^{* * *} p<0.001\right)$

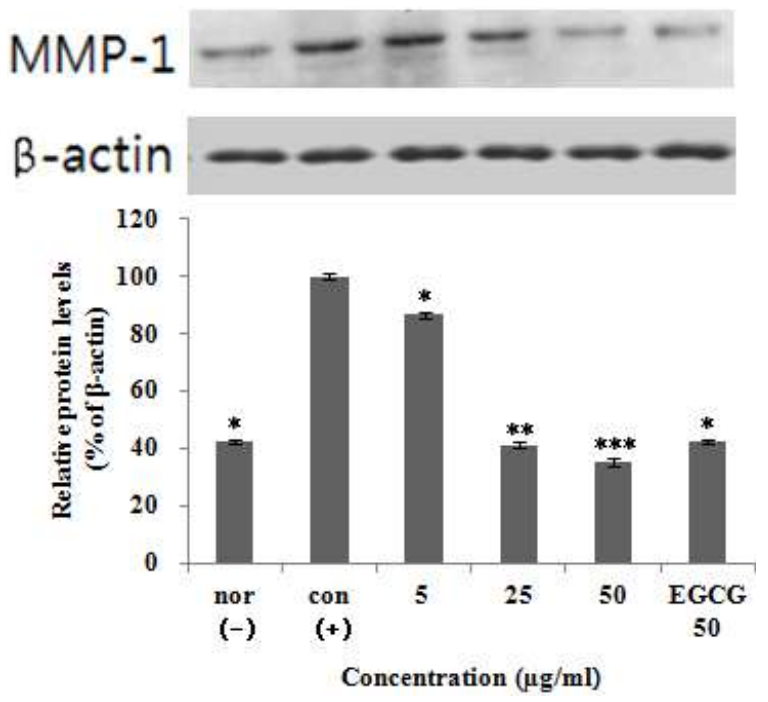

Fig. 6. MMP-1 protein expression rate of extract from Smilax china L. on fibroblast cell (CCD-986sk). After CCD-986sk cells $\left(5 \times 10^{5}\right.$ cells) were started in serum free medium for $1 \mathrm{~h}$ the cells were treated with 5,25 and $50 \mu \mathrm{g} / \mathrm{ml}$ of ethanol extracted of Smilax china L. (SC) for $24 \mathrm{~h}$. Each value represents mean \pm SD of three individual experiments. (Significant as compared to control. ${ }^{*} p<0.05$, $\left.{ }^{* *} p<0.01,{ }^{* * *} p<0.001\right)$

단백질 발현을 측정한 결과 $50 \mu \mathrm{g} / \mathrm{ml}$ 의 농도에서 $35 \%$ 의 저해 율을 나타내었고, $\mathrm{mRNA}$ 발현을 측정한 결과 $50 \mu \mathrm{g} / \mathrm{ml}$ 의 농 도에서 $45 \%$ 의 저해율을 나타내었다. 따라서 청미래덩굴 에탄 올 추출물이 주름생성 억제 활성을 보이는 것으로 판단된다. 

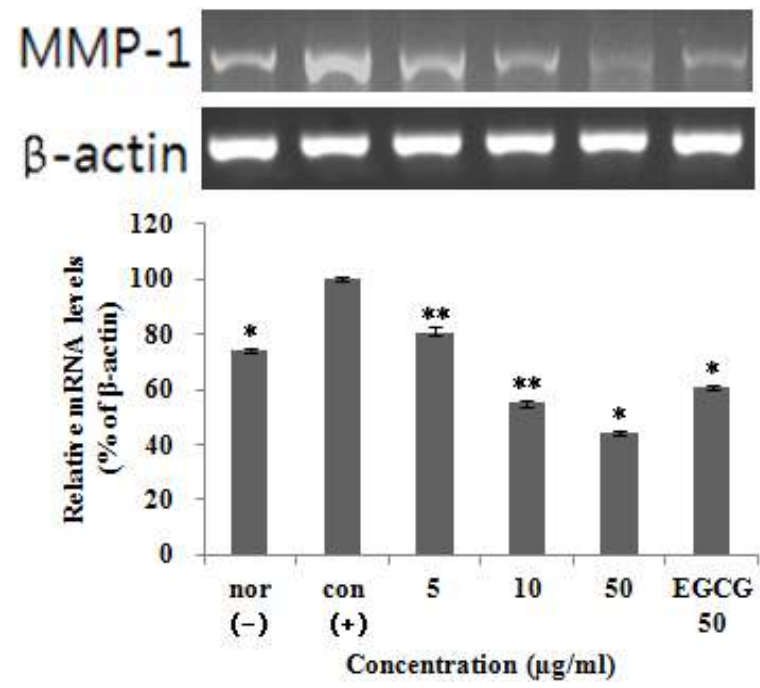

Fig. 7. MMP-1 mRNA expression rate of extract from Smilax china L. on fibroblast cell (CCD-986sk). After CCD-986sk cells $\left(5 \times 10^{5}\right.$ cells) were started in serum free medium for $1 \mathrm{~h}$ the cells were treated with 5,25 and $50 \mu \mathrm{g} / \mathrm{ml}$ of ethanol extracted of Smilax china L. (SC) for $24 \mathrm{~h}$. Each values represents mean $\pm \mathrm{SD}$ of three individual experiments. (Significant as compared to control. ${ }^{*} p<0.05$, $\left.{ }^{* *} p<0.01,{ }^{* * *} p<0.001\right)$

이러한 결과로 미루어 보아 청미래덩굴 에탄올 추출물이 elastase 및 collagenase 저해활성, 섬유아세포의 생존율, procollagen type- I 생합성량, MMP-1 저해활성 등에서 효능이 있음을 확인할 수 있었으며, 주름개선용 화장품 소재로 응용 이 가능할 것으로 판단된다. 차후 화장품 제형에서 청미래덩 굴 추출물이 얼마나 안정하게 포집되어 피부에 적용이 되는지 에 대한 연구가 계속된다면 우수한 주름개선용 화장품 천연 소재가 될 것으로 생각된다.

\section{감사의 글}

본 연구는 보건복지부 보건의료연구개발사업의 지원에 의 하여 이루어진 것임. (과제고유번호: A103017)

\section{References}

1. Cannell, R. J., Kellan, S. J., Owsianks, A. M. and Walker, J. M. 1988. Results of a large scale screen of microalgae for the production of protease inhibitors. Planta Med54, 10-14.

2. Carmichael, J., DeGraff, W. G., Gazdar, A. F., Minna, J. D. and Mitchell, J. B. 1987. Evaluation of a tetrazolium-based semiautomated colorimetric assay: assessment of chemosensitivity testing. Cancer Res 47, 936-942.

3. El-Domyati, M., Attia, S., Saleh, F., Brown, D., Birk, D. E., Gasparro, F., Ahmad, H. and Uitto, J. 2002. Intrinsic aging vs. photoaging: a comparative histopathological, immunohistochemical, and ultrastructural study of skin. Exp
Dermatol 11, 398-405.

4. Giacomoni, P. U. and Rein, G. 2001. Factors of skin ageing share common mechanisms. Biogerontology 2, 219-229.

5. Gross, J. and Lapiere, C. M. 1962. Collagenolytic activity in amphibian tissues: a tissue culture assay. Proc Natl Acad SCi USA 54, 1197-1204.

6. Jeroma, S. P., Gabrielle, L. and Raul, F. 1998. Identification of collagen fibrils in scleroderma skin. J Invest Dermatol 90, 48-54.

7. Kim, D. H. 2011. The study on verification of skin pharmacological mechanism from useful compound of Aruncus dioicus and special cosmetic formular. Ph. D. dissertation, Daegu Haany University, Gyeongbuk, Korea.

8. Kondo, S. 2000. The roles of cytokines in photoaging. $J$ Dermatol Sci 23, 30-36.

9. Lee, J. Y., Park, W. S., Son, E. D., Ahn, S. M. and Hwang, J. S. 2007. In vitro evalution methods for the development of cosmeceutical ingredients. J Alternat Animal Exp 1, 33-40.

10. Lim, A. K., Kim, J. O., Jung, M. J., Jung, H. K., Hong, J. H. and Kim, D. I. 2008. Functional biological activity of hot water and ethanol extracts from Taraxaci Herba. J Korean Soc Food Sci Nutr 37, 1231-1237.

11. Nagase, H. and Woessner, J. F. Jr. 1999. Matrix metalloproteinase. J Biol Chem 274, 21491-21494.

12. Seo, I. A. 2010. Studies on cosmeceutical of Phaseolus radiatus. M. S. dissertation, Daegu Haany University, Gyeongbuk, Korea.

13. Shao, B., Guo, H., Cui, Y., Ye, M., Han, J. and Guo, D. 2007. Steroidal saponins from Smilax china and their anti-inflammatory activities. Phytochemistry 68, 623-630.

14. Song, H. S., Park, Y. H., Jung, S. H., Kim, D. P., Jung, Y. H., Lee, M. K. and Moon, K. Y. 2006. Antioxidant activity of extracts from Smilax china Root. J Korean Soc Food Sci Nutr 35, 1133-1138.

15. Talwar, H. S., Griffiths, C. E., Fisher, G. J., Hamilton, T. A. and Voorhees, J. J. 1995. Reduced type I and type III procollagens in photodamaged adult human skin. I Invenst Dermatol 105, 285-290.

16. Wang, Y., Johnson, A. R., Ye, Q. Z. and Dyer, R. D. 1999. Catalytic activities and substrate specificity of the human membrane type 4 matrix metalloproteinase catalytic domain. J Biol Chem 274, 33043-33049.

17. Wlaschek, M., Tantcheva-Poor, I., Naderi, L., Ma, W., Schneider, L. A., Razi-Wolf, Z., Schuller, J. and ScharffetterKochanek, K. 2001. Solar UV irradiation and dermal photoaging. I Photochem Photobiol B 63, 41-51.

18. Wu, L. S., Wang, X. J., Wang, H., Yang, H. W., Jia, A. Q. and Ding, Q. 2010. Cytotoxic polyphenols against breast tumor cell in Smilax china L. J Ethnopharmacol 130, 460-464.

19. Wúnsch, E. and Heindrich, H. G. Zur. 1963. Quantitativen bestimmung der collagenase. Hoppe-Seyler's Physiol Chem 333, 149-151.

20. Yang, K. H. 2004. Studies on the antioxidation and antimicrobial effect of smilacis glabrae rhizome. J Korean Oriental Med 25, 1-8. 
초록 : 섬유아세포(CCD-986sk)에서 청미래덩굴의 pro-collagen type-1 활성 및 MMP-1의 유전자 발현 저해능

이수연 · 이진영*

(호서대학교 한방화장품과학과)

청미래덩굴 추출물의 주름개선 효과를 확인하기 위해 elastase 저해활성을 측정한 결과 청미래덩굴 에탄올 추 출물과 열수 추출물이 $1,000 \mu \mathrm{g} / \mathrm{ml}$ 에서 각각 $41.1 \%, 16.3 \%$ 의 활성을 나타내었으며, collagenase 저해활성 측정 결과 청미래덩굴 에탄올 추출물과 열수 추출물이 $1,000 \mu \mathrm{g} / \mathrm{ml}$ 에서 각각 $96.6 \%, 60.0 \%$ 의 활성을 나타내었다. 청미 래덩굴의 에탄올 추출물의 세포생존율을 확인하기 위하여 섬유아세포(CCD-986sk)로 MTT assay에 의해 확인한 결과 $50 \mu \mathrm{g} / \mathrm{ml}$ 농도에서 $71.7 \%$ 의 세포 생존율을 확인할 수 있었다. 섬유아 세포에서 청미래덩굴 에탄올 추출물의 pro-collagen type-1 생합성량을 확인한 결과 $50 \mu \mathrm{g} / \mathrm{ml}$ 의 농도에서 $139 \%$ 이상의 우수한 효과를 나타내었으며, MMP-1 저해활성을 측정한 결과 $50 \mu \mathrm{g} / \mathrm{ml}$ 의 각각의 농도에서 $74.9 \%$ 의 활성을 나타내었다. 청미래덩굴 에탄올 추출물을 처리한 섬유아 세포에서 MMP family 중 MMP-1의 단백질 발현 및 mRNA 발현 억제 효과를 확인한 결과 MMP-1 단백질 발현과 mRNA 발현 모두 $50 \mu \mathrm{g} / \mathrm{ml}$ 에서 각각 $35 \%, 45 \%$ 의 저해율을 나타내었다. 이러한 결 과로 미루어 보아 청미래덩굴 에탄올 추출물이 주름개선용 화장품 소재로 응용이 가능할 것으로 판단된다. 